Rev. Tadeusz Kasabuta University of Bialystok

\title{
The Statutes of the Cathedral Chapter of Vilnius Before the Partition of Poland
}

After being canonically erected in 1388 , the Cathedral Chapter of Vilnius did not have any recognized privileges or land grants. It subsisted exclusively off of the bishop of Vilnius' bona mensae, and it followed the Cathedral Chapter of Cracow's example with regard to its organization, internal structure, activities, and relationship with the diocesan bishop. Having certain privileges and revenue at its disposal in the 15th century, the canonical corporation of Vilnius began to seek greater legitimacy. It was not until 1515, however, that Bishop Wojciech Radziwiłł ordered that the Chapter write up its rights and duties in the form of statutes and that the Holy See approve them. Pope Leo X subsequently approved the Cathedral Chapter of Vilnius' statutes through his legate Bishop Zacharias Ferreri on November 29, 1520. The papal confirmation gave the Cathedral Chapter of Vilnius strong legal standing that no one, with the exception of the Holy See, could violate or change. The statutes strengthened the Chapter's position in relation to the diocesan bishop, which turned out to be both in accordance with the spirit of the times and, with time, affirmed by the Council of Trent (1545-1563).

Key words: Grand Duchy of Lithuania, Vilnius, cathedral chapter, statute, legal norm, confirmation, Holy See.

Cathedral chapters were not always institutions established to govern the diocese. Their basic tasks were to carry out daily divine service in the cathedral and to support the ordinary bishop in governing the diocese. These colleges also controlled the bishop's administrative activities. Specifically, the college of prelates and canons would take a stance on the bishop's decisions by voting. If the college approved of the bishop's decision, then they would issue an act of agreement, 
and only then would the decision become legally valid. One of the chapter's more important duties was to control administration of its bona mensae. ${ }^{1}$

The Cathedral Chapter of Vilnius was established by virtue of Pope Urban VI's papal bull Romanus Pontifex on March 12, $1388 .{ }^{2}$ Bishop Dobrogost of Poznań carried out the papal order that very same year and established a capitular college at the newly erected cathedral. Initially, this college was made up of two prelates and ten canons. ${ }^{3}$ At the beginning, the Chapter did not receive any privileges or land grants. It subsisted only from the Bishop of Vilnius' bona mensae. The Cathedral Chapter of Vilnius followed the Cathedral Chapter of Cracow's example ex consuetudine with regard to its organization, internal structure, activities, and relationship with the diocesan bishop. ${ }^{4}$ Beginning in 1390, the Cathedral Chapter of Vilnius gradually gained more independence in terms of property due to the first grants that King Ladislaus Jagiełło and Prince Vitold conferred on it. ${ }^{5}$ Subsequent rulers and minor donors successively increased this revenue. Thanks to these foundations, the Vilnius Chapter became a completely selfsufficient corporation in terms of its organization and finances in a relatively short amount of time. ${ }^{6}$

With certain privileges and grants at its disposal, the capitular col-

History of the Church lege began to seek increasingly greater legitimacy, which was essential

$1 \quad$ W. M. Plöchl, Geschichte des Kirchenrechts, Bd 3, Teil 1, Wien 1969, 299-300; S. Zachorowski, Rozwój i ustrój kapitut polskich w wiekach średnich, Kraków 1912, 68-69, 217-224.

2 Kodeks dyplomatyczny katedry i diecezji wileńskiej, eds. J. Fijałek, W. Semkowicz, vol. 1, z. 1, Kraków 1948, (abbreviated hereafter as: KDKDW), no. 10, 20 nn.

3 The two dignities established at that time were provost and dean, both of who were prelates. KDKDW, no. 13, 24-26.

4 KDKDW, no. 13, 26; J. Kurczewski, Kościót zamkowy czyli katedra wileńska $w$ jej dziejowym, liturgicznym, architektonicznym i ekonomicznym rozwoju, Part 2, Wilno 1910, 11-14; Idem, Biskupstwo wileńskie od jego założenia a $\dot{z}$ do dni obecnych, Wilno 1912, 105.

5 The following critically issued documents contained in the Diplomatic Codex of the Cathedral and Diocese of Vilnius [Kodeks dyplomatyczny katedry i diecezji wileńskiej] confirm the first foundations that made the Cathedral Chapter of Vilnius economically self-sufficient: no. 17, 31 (the goods of Ponar-1390), no. 20, 35 (the goods of Strzeszyn - 1391), no. 25, 41-42 (the goods of Cudzieniszki 1395), no. 28, 46-47 (the two lakes in the isle of Tauragè, the three town squares in Vilnius, the tithes of more than a dozen villages - 1397).

$6 \quad$ J. Ochmański, Powstanie i rozwój latyfundium biskupstwa wileńskiego (13871550), Poznań 1963, 106-110. 
once the first Bishop of Vilnius, Andrew Jastrzębiec, died in 1938 and the Chapter elected the Franciscan, Jacob Pluchta, as bishop and appointed him on May 5, 1399. Before the newly appointed bishop's formal ingress, the capitular body hurried to show Jacob Pluchta the acts that documented their privileges as well as another document that contained their six demands. More specifically, the canons expected that the newly appointed shepherd of the diocese defend the legal rights of the cathedral church and ensure that that due honor was shown to it; not force them to reside at the cathedral; not do anything to oppose the Chapter's rights; defend the Chapter against outside claimants; care for the increasing number of parishes and appoint diocesan priests to oversee them; carry out his predecessor's will, particularly concerning the grants and records that favored the Chapter; settle all disputes with the Chapter as a corporation or with its particular members by accepting the decision of the capitular conciliation court; and grant the Chapter the right to enact judgments and inflict ecclesial censures, including excommunication, on anyone who infracted on ecclesiastical goods and property. Due in part to the pressure that Prince Vitold put on him, Bishop Jacob promptly approved these postulates. ${ }^{7}$ Neither the form nor the content of the approved document resembles legal norms; therefore, strictly speaking the document does not contain the Cathedral Chapter of Vilnius' statutes. Similar kind of conduct on the part of the Chapter is further evidence of this. For now, this was the first time the Chapter, having referred to the statutes of the Cathedral Chapter of Cracow, presented its postulates, suggestions, and questions to the bishop; conferred with him on current affairs; and collaborated as the two decision-making bodies of the diocese to come to a cooperative decision-a custom that was eventually enacted into law and was used in the Diocese of Vilnius until the end of the $18^{\text {th }}$ century. The statutes of the Cathedral Chapter of Vilnius evolved differently, however, although at the same pace as the Cathedral Chapter of Cracow. The relationship of the Cathedral Chapter of Vilnius as a corporation and its particular members with the ordinary as well as the scope of the rights and competences of both governing entities were based on the appointed and well-established rights of the Cathedral Chapter of Cracow, the customs and organization of which served as a model for the Vilnius Chapter, which was in the beginning stages of its formation.

KDKDW, no. 35, 63-64; W. Pawlikowska-Butterwick, L. Jovaiša, Vilniaus ir žemaičiu katedru kapitulu statutai, Vilnius 2015, 23-24, 121-122. 
The Chapter's first "statutes" are mentioned in a document written when Bishop Maciej from Trakai (1422-1453) was governing the diocese. This document is rather mysterious. The context of this document remains unknown, and it is difficult to determine whether the contents constitute statutes. The fact is, the document normalized the allocation of half of the honey tribute to the bishop. ${ }^{8}$ Further terms that were determined in 1486 pertained to dividing the Mass and funeral offerings between the bishop and Chapter. ${ }^{9}$ Based on these vestigial and other more general norms and in cooperation with the bishop, the Chapter determined particular norms tailored to meet both its and the diocese's current needs. This system worked until the beginning of the $16^{\text {th }}$ century. Naturally, this was a satisfactory solution neither for the bishop nor the Chapter. As disputes between the bishop and the Chapter arose, both parties were forced to compromise because the Cracow Chapter's statutes did not foresee and provide examples of solutions to these disagreements. One such serious case took place after the death of Prince Casimir and concerned the distribution of goods that the deceased had left to the diocese. This situation revealed the general problem of distributing the goods of bishops, members of the Chapter, and religious and clergy after they died without leaving a will. The matter escalated to such a degree that the case was brought of the Church before the arbitration court on September 2, $1486 .{ }^{10}$ Even though the dispute was resolved, neither party was fully satisfied with the verdict. Therefore, the Chapter did not delay in obtaining an "acknowledgment of the privileges and immunity of the Church and religious" from the Grand Duke of Lithuania Alexander Jagiellończyk in August 1492. ${ }^{11}$ Although the disagreement ceased, the entire matter more clearly revealed the Chapter's need to be legitimized so that it could handle different kinds of disputes.

Another serious sign that it was necessary to determine more precisely the rights and obligations of the Cathedral Chapter of Vilnius was a dispute between the Chapter and Bishop Wojciech Tabor that occurred in 1503. This disagreement concerned the interpretation of the

\footnotetext{
KDKDW, no. 348, 408.
}

9 KDKDW, no. 348, 408-409; J. Kurczewski, Biskupstwo wileńskie, 30-31.

10 KDKDW, no. 348, 406-411.

11 "Omnia et singula bona, dominia, hereditates, possessiones, districtus et villas literasque ac privilegia, gratias, libertates, necnon immunitates eorundem [...] venerabili ecclesiae Vilnensi cathedral et suo capitulo datas, donates et concessas ratificara, confirmare, gratificare, approbare et innovare dignaremur." KDKDW, no. 389, 446-447. 
privilege that Pope Alexander VI bestowed on the Chapter in 1501. The privilege gave the Chapter the right to prosecute and inflict Church censures on those who violate the Chapter's privileges and property. ${ }^{12}$ Because this privilege contradicted the land court's resolutions and the diocesan bishop's rights, it was necessary to include an addendum to explain it. The compromise that was reached at the time upheld the papal privilege, but gave those who were under ecclesiastical censure the right to appeal to the metropolitan (ad metropolitanum recurrere). ${ }^{13}$

The aforementioned and other smaller disputes hindered and even paralyzed diocesan governance, which ultimately prompted Bishop Wojciech Radziwiłł to determine with the Chapter's consent "that all previous and more recent decisions made by his predecessors in different times and various forms be compiled into one book and that, after the Chapter reviewed it at the general session, he would make it legally binding on the Feast of the Translation of Relics of St. Stanislaus, the patron saint of the cathedral, and, in order to make his act more solemn, insist that the [statutes] be apostolically approved in Rome." Although the document entitled Statuta inclite Ecclesiae cathedralis Vilnensis ac Sacre divi Stanislai sedis tam a venerabili Capitulo, quamcuius pontificalibus edita et a $S^{\frac{m a}{}}$ Sede Apostolica confirmata A. 1515 was ready to be promulgated in the diocese in 1515, Bishop Wojciech asked the Holy See to approve them first. ${ }^{14}$ Since, however, the Fifth Lateran Council was underway (1512-1517), the circumstances were not conducive to settling the matter promptly and, because of the council's resolutions, the Chapter had to correct and complete the necessary documents before the statutes could be approved..$^{15}$ Because Bishop Radziwiłł had delayed for three years, he promulgated the document within his diocese in 1518-one year after the Council of Trent had ended-without waiting for pontifical approval. The bishop could have been in a hurry because he knew that he did not have long to live; he subsequently passed away on April 19, 1519. In Rome at that time, the need to approve the statutes of the Cathedral Chapter of Vilnius became so pressing that Pope Leo X decided to carry out

12 Lietuvos Mokslų Akademijos Vrublevskių Biblioteka - rankraščių skyrius (abbreviated hereafter as: LMAB), f. 43-207, Index libri actorum V. Capituli Vilnensi, k. 2-2v; KDKDW, no. 495, 595-596.

KDKDW, no. 565, 680-684.

Polish Academy of Science Library, Cracow, Ref. 1963, Statuta inclite Ecclesiae cathedralis Vilnensis ac Sacre divi Stanislai sedis tam a venerabili Capitulo, quamcuius pontificalibus edita et a $\mathrm{S}^{\mathrm{ma}}$ Sede Apostolica confirmata A. 1515.

W. Pawlikowska-Butterwick, L. Jovaiša, 42-44, 141-143. 
this act through his legate the Titular Bishop of Gardien, Zacharias Ferreri, at the end of $1520 .{ }^{16}$ At that time, however, King Sigismund was making great efforts to ensure that Prince Casimir, who had died a holy man, would be canonized. The investigation into the cult of this candidate for sainthood demanded more of the papal legate's attention than the approval of the Cathedral Chapter of Vilnius' statutes, which he, nevertheless, carried out in Vilnius on November 29, 1520.17 At that time, the 20-year old son of King Sigismund I the Old, John of the Lithuanian Dukes, had been the Bishop of Vilnius since September 23,1519 . In the acts of papal confirmation, his name appears last in the list of the bishops of Vilnius, which suggest that he had brought his predecessor's work to completion. He also had the privilege to place the seal of approval under the signatures of the legates, even though he had hardly been involved in the entire matter. ${ }^{18}$ The truth be told: Bishop Wojciech Radziwiłł had done the most to ensure that the statutes of the Cathedral Chapter of Vilnius were prepared, recorded, and subsequently approved by the Holy See. ${ }^{19}$

The original document containing the statutes, which were divided into eighty chapters, has not survived. Only copies of passages from the original remain, and they can be found in later documents. While these copies are faithful to the sense of the original, they differ in the of the Church details. These passages refer to Bishop Ferreri's approval given on November 29, 1520, in which assured the Cathedral Chapter of Vilnius on behalf of the Holy See that "the freedoms and privileges, the customs, decisions, and resolutions that have benefitted the chapter and have already been legally enacted will continue into the future." All of the conferrals and privileges that had been granted by previous

16 LMAB, f. 43-152, Summa Privilegiorum, Immunitatis, Exemptionum, Libertatum ceterarum eiusmodi Gratiarum in rem ac favorem Status Spiritualis et respective Cathedrae Vilnensis eiusque Illmi Capituli servientium, ex ipsis originalibusad promtiorem notitiam: Confirmatio omnium privilegiorum et Immunitatum exemptionum statutorum venerabile capitulo Vilnensi servientium per Zachariam episcopum Gardiensem ad regnum Poloniae et M. Ducatus Lituniae nuntium apostolicum facta a. 1520 bris 29 d., k. 3. Fr. J. Kurczewski reprinted this document in extenso in his work Kościót zamkowy, Part 2, Vilnius 1910, 35-37.

17 Zacharias Ferreri, "absorbed with and captured by the cult [that he was investigating], he thought it fit to honor Casimir by composing a hymn in Latin and removing his biography." W. Zaleski, Święci na każdy dzień, Warszawa 1989, 111. T. Ulewicz, Iter Romano-Italicum-Polonorum, czyli o zwiazkach umystowokulturalnych Polski z Włochami w wiekach średnich i renesansie, Kraków 1999, 172.

LMAB, f. 43-152, Summa Privilegiorum, k. 3. 
popes were legitimized during the approval, and "due to the particular fact that the Church and chapter in Vilnius were compared to the bishopric of Cracow in the their complete and free jurisdiction and possession of power over vicars, custodians, and assistant priests, that is chaplains and seminarians who belong to the Church of Vilnius [...], the affairs of every member of the chapter must be settled by none other than the chapter itself or, ultimately, the Holy See and those are legally authorized to represent it [...] These chapters enjoy other privileges both legally and in accordance with justice. Furthermore, in order to sustain all members of future Vilnius chapters, polish Kings, Lithuanian dukes, and Catholic landlords legally give, offer, or and record the following [to the chapter]: lands, rivers, lakes, streams, mills, bridges, pastures, groves, forests, fields, tithes, granges, granaries, houses, villages, castles, cities, and all other moveable and immoveable goods, including their rights and affiliations." The papal legate pronounced that all of these endowments and privileges taken together and individually were henceforth legally binding and, therefore, inviolable. Moreover, he instructed all of the clergy and laity to "respect all of these rights and endowments in every way according to the measure of respect due to the Holy See itself." He appointed the Bishops of Cracow and Euck curators of the Cathedral Chapter of Vilnius to "always defend all of these rights, individuals, or the entire cathedral chapter of Vilnius, provide necessary aid, prosecute all obstinate and unlawful usurpers and troublemakers by virtue of the law and inflect ecclesiastical censures, disregard any provisions that are contrary to them, and refute any seemingly Apostolic ordinances that may appear valid but, based on the information contained herein, are not authorized by he Holy Father."20

This was truly a momentous act with regard to the structure and organization of the Cathedral Chapter of Vilnius. The papal confirmation gave it a legal standing that no one except the Holy See could violate or change. The statutes primarily strengthened the Chapter's position in relation to the diocesan bishop, since the Chapter no longer needed to ask the bishop to approve its legal status. From here forward, every newly appointed diocesan bishop took an oath to maintain the Chapter's position within the diocese according to the statutes. If tensions between the Chapter and the bishop arose, then they concerned only the interpretation of individual statutes and not their essence. Even in such instances, however, the Holy See was the arbiter. As early as 1525, Bishop John of the Lithuanian Dukes became convinced of this 
state of affairs. Because of the Chapter's unwillingness to compromise, Pope Clement VII settled the bishop's claims regarding the Chapter's income from a property in Chervyen. ${ }^{21}$ The Chapter itself was also surprised by its strong legal standing; for, in 1625, a dispute about the distribution of bona mensae arose among the canons-a disagreement that had to be resolved by Pope Urban VIII rather than the ordinary, Bishop Eustachy Wołłowicz. ${ }^{22}$

Copyists made many mistakes when copying the text of the capitular statutes that the Holy See confirmed and that then had been revised and added on to. It is very likely that the version that the papal legate Zacharias Ferreri confirmed contained errors and inaccuracies. This fact came to light and was recorded in the minutes of one of the capitular sessions. Specifically, on October 1, 1521, during the autumn session, Canon Jan Silvius Amatus from Italy (noted as Sicilian in the document) was instructed to examine the statutes carefully and correct and organize them..$^{23}$ Jan the Sicilian was not a trained lawyer and did not know anything about law. Instead, he was a humanist, rhetorician, expert in Greek literature, a professor at the University of Cracow, and-at the order of Queen Bona Sforza-Sigismund August's teacher. ${ }^{24}$ The fact that he was entrusted with this job suggests that the Chapter was not primarily concerned with the legal nature of of the Church the statutes but rather the linguistics. Silvius Amatus completed the task satisfactorily, which was evidenced by the fact that this matter was not mentioned in future documents. At this point, therefore, the statutes' literary form was sound-something that had been lacking previously. Soon afterward, the Chapter made it a practice to read all of the statutes during the opening of every general session until the end of the $17^{\text {th }}$ century. ${ }^{25}$ In fact, the book containing the statutes was used so frequently that the Chapter decided to make one official copy, which served as the exemplar for all copyists, so that they could avoid errors. The Chapter made this decision during the autumn general session on October 2, 1535, when the capitular notary was ordered to rewrite the statutes "precisely and with great care on parchment

21

J. Kurczewski, Kościót zamkowy czyli katedra wileńska w jej dziejowym, liturgicznym, architektonicznym i ekonomicznym rozwoju, Part 3, Vilnius 1916, 15, 26.

LMAB, f. 43-217, ACV, vol. 9 (1625-1632), k. 5-5v.

J. Kurczewski, Kościót zamkowy, Part 3, 12.

K. Morawski, Czasy Zygmuntowskie na tle pradów Odrodzenia, Warszawa 1965 , 69-70.

25 J. Kurczewski, Kościót zamkowy, Part 3, 25. 
using the previous script." Ten polish zlotys, which was a considerable amount at that time, was allocated for this project. ${ }^{26}$

Copies of the statutes record some of the subsequent endowments and privileges that were given to the Cathedral Chapter of Vilnius and approved by the Holy See, while other endowments and privileges were recorded in the original versions of the statutes and kept in the archives. This meant that the laboriously created statutes ceased to be kept together in one record. In addition, referring to a book daily that was laden with additional documents and announcements of new appointments and privileges had become impractical over time. It is no surprise then that the canons who regularly referred to the book during sessions demanded that the contents be summarized so that the legal value of the document be preserved. This handy collection of statutes was prepared in the second half of the $16^{\text {th }}$ century. It is impossible to determine who did this job. The fact is, however, that the new collation entitled Statuta inclitae Ecclesiae Cathedralis tam a Venerabili Capitulo quam eius Pontificibus edita tum a Sanctissima Sede Apostolica confirmata was already in use by 1584 . This updated version, which had been edited and laid out in a different manner, had removed contradictory articles and added new documents that explained certain articles. ${ }^{27}$ After several decades, however, this version of the statutes was no longer satisfactory. Therefore, on February History 3,1649 , three members of the Chapter adopted a resolution to begin working on a summary of the statutes so that they could "always be on hand during the sessions." 28 They also noted that the current list of statutes had ceased to be relevant, was no longer suited to the changing times, and did not reflect the new face of the Catholic Church after the Council of Trent. ${ }^{29}$ Needless to say, this important legal document needed to be updated once again. The question arises, however, why this matter was not officially discussed at the capitular sessions until more than 80 years after the Council of Trent took place. This delay was due to the fact that the council's resolutions were not readily accepted in Poland for many reasons. In the case of cathedral chapters, including the Cathedral Chapter of Vilnius, the main issue-albeit not the only one-was the Council of Trent's resolutions that prohibited

$26 \quad$ Ibid., 34 .

$27 \quad$ LMAB, f. 43-155, Statuta inclitae Ecclesiae Cathedralis tam a Venerabili Capitulo quam eius Pontificibus edita tum a Sanctissima Sede Apostolica confirmata, [ok. 1584]. 
the accumulation of benefices and the order to reside at them. However, since the issue of residence and the accumulation of benefices applied to the entire Catholic Church in Poland and was resolved over time with the help of a dispensation from the Holy See, it was not the reason why the Cathedral Chapter of Vilnius waited so long to update its statutes. The Vilnius Chapter was more concerned with the fact that the statutes that were favorable to it and that gave the Chapter a strong position in relation to the bishop would have to be submitted to and confirmed by the Holy See after they had been updated. Moreover, the registers that were stored in the capitular archive at that time convey that many bulls and other papal documents, privileges, and private charters were destroyed during fires and war. The information that the prelate archdeacon provided on November 18, 1592 testifies to this fact; he records that "many privileges were destroyed in the fire." ${ }^{30}$ A consistory writer made a similar report in 1611, stating that the fire that occurred in the city in 1610 "destroyed many cathedral papers, books, memorabilia, and the entire former recorded contained in a large chest located above the archway of the bishop's home." ${ }^{1}$ Therefore, it was exceptionally difficult to try to re-document the many privileges contained within the statutes. On October 3, 1650, the points

History for consideration that the newly appointed bishop, Jerzy Tyszkiewicz, of the Church had written up and given to the Chapter for the general session stated that, as a matter of urgency, they must adapt the capitular acts to the rules of the Council of Trent and submit them to the Holy See to be confirmed. In response, the Cathedral Chapter of Vilnius delegated certain canons to do this work. ${ }^{32}$ Which canons were delegated to do this job remains unknown. It is known, however, that the commission did very little_or rather, nothing — for almost one year because, once again, the bishop "urged them to revise the statutes according to the degrees of the Council of Trent and universal law" on October 3,1651 . This time, the Chapter took the matter more seriously and appointed a commission of four members, including Prelate Dean Jerzy Wołłowicz and the three canons Jerzy Bałłozor, Maciej Słupski, and Wawrzyniec Mocarski to do the work. They were competent and experts in law, which gave the Chapter hope that the job would be

$30 \quad$ LMAB, f. 43-215, ACV, vol. 7 (1586-1601), k. 207; "Summaryjny wypis z protokołów Kapituły Katedralnej Wileńskiej od r. 1501 do r. 1783 Października 22, przez i. w. Xawierego Bohusza, Prałata Kantora Kathedry Wileńsiey uczyniony," in: Opisanie rukopisnago otdielenia Wilenskoj Publicznoj Biblioteki, wypusk 1, Wilna 1895, 68. 
completed promptly. ${ }^{33}$ The commission likely began work in 1651 and made some progress, but then the members of the capitular college who were most knowledgeable in law became embroiled in in a dispute with the Jesuits about the rights of the founder of St. John's church. ${ }^{34}$ Therefore, when the matter was brought up at the autumn general session on October 7, 1652, the canons who were delegated to the task of updating the statutes were told to complete their work during the upcoming advent. ${ }^{35}$ It is difficult to say to what extent the commission's efforts were effective because, when the bishop asked the canons for an update on their progress, they replied that the work concerning the corrections had not yet been completed due to the plague that had spread to Vilnius that year. ${ }^{36}$ In addition, the canons who had been delegated to correct the text were appointed as Chapter delegates to the sejm. This prolonged the work on the statutes for another year, during which very little progress was made. On May 13, 1654, the Chapter was so determined to complete the work that it took the initiative and appointed a new commission to edit the statutes without the bishop's prompting. This time the commission was made up of the Prelate Cantor Jan Newelski, the canons Wawrzyniec Mocarski and Andrzej Brazgalski, and the chancery and diocesan auditor (who was not a member of the Chapter), Fr. Marcjan Florian Wciśliński. This commission was ordered to commence work immediately after the octave of Corpus Christi. The Chapter also unanimously adopted a resolution to send the statutes to Rome immediately after the work was completed in order to obtain the Holy See's approval as quickly as possible. ${ }^{37}$ Why the Chapter chose this particular committee remains unknown. Taking the entire context of the Chapter's activity into consideration, however, it is possible to draw some different conclusions. The main criteria for choosing these individuals most likely was the fact that they were the least burdened with other work because, apart from Canon Mocarski, none of the other members had experience in law or working in the chancery office. The commission made measurable progress in its work. In 1655, the Chapter once again tried to complete the project of editing the statutes. On May 13 of that same year, the Chapter delegated the Prelate Cantor Newelski, Fr. Wciśliński (from the previous commission), and the canons Adam Kopcie and Paweł Kleczkowski to

33 Ibid., 957.

$34 \quad$ Ibid., 935, 949, 953.

35 LMAB, f. 43-221, ACV, vol. 13 (1652-1663), k. 40.

36 Ibid., k. 84-84v.

37 Ibid., k. 130. 
do the work. Canon Jerzy Wołłowicz also returned to help. ${ }^{38}$ However, they were unable to make very much progress because Moscow's army had reached the gates of Vilnius, thus forcing the Chapter to abandon the city, which the invading force occupied on August $10 .{ }^{39}$

After the war ended and the Chapter returned to Vilnius, it hardly considered reforming the statutes to reflect the spirit of the Council of Trent because the capitular archives had been seriously damaged when Moscow invaded. In addition, because the files had been moved repeatedly from place to place, part of the collection had either been damaged or lost altogether, which the capitular "protestation" in 1662 indicates. ${ }^{40}$ After returning from Rome in 1697, Bishop Constance Casimir Brzostowski incidentally mentioned the need to reform the statutes when he gave the Chapter his points for consideration, which included an appeal to the Chapter to reform the divine service "at its head as in its members," meaning both in the cathedral and among the diocesan the clergy, based on the privileges and statutes and taking into consideration Council of Trent's resolutions. This reference proves that, after the turmoil that had taken place from 1654-1662, they had given up on their efforts to have Holy See confirm the statutes again. Subsequent bishops who took up this issue were only interested in ensuring that the Chapter behaved and followed the statutes. In matters of the Church that involved the Council of Trent's resolutions, the bishops referred directly to the universally available decree Tridentinum, and not to the statutes. This was the tone in which Bishop Michael Zienkowicz wrote his 18-point decree on reform after making a visitation to the Vilnius cathedral in May 1743. Within the first sentence of the document, the inspector earnestly advised the Chapter as both a corporation and as individual members to follow strictly the statutes, synodal decrees, and laws of the universal Church. ${ }^{41}$

During its displacement when the invasion of Moscow occurred, the Chapter was not concerned about preparing a new edition of the statutes. In order for the Chapter to simply function, it adopted a version that had emerged after rather superficial changes that did not alter the

38

39 Ibid., k. 198.

L. Kubala, Wojna moskiewska, 1654-1655, Warszawa 1910, 288-289; A. Rachuba, "Wilno pod okupacją moskiewską w latach 1655-1661," Lithuania, 1994, nos. 2-3: 65-66.

LMAB, f. 43-221, ACV, vol. 13 (1652-1663), k. 311-311v.

41 Ecclesiae Cathedr. Vilnen. Ab Ill'mo Excell'mo a Rndmo Dn Michaele Ioanne Zienkowicz Episcopo Vilnensi Loc. Or. Anno Dni 1743 Die 13 Maij expedita, 328. A summary of the same: J. Kurczewski, Kościót zamkowy, Part 2, 279-304. 
meaning of the statutes had been made in the $1650 \mathrm{~s}$. The document that the Cathedral Chapter of Vilnius used during the second half of the $17^{\text {th }}$ century and throughout the entire $18^{\text {th }}$ century does not contain references to the findings of the Council of Trent. ${ }^{42}$

The version of the statutes that existed after 1662 (which had been drafted in 1584) contained 66 articles, which is little more than a dozen fewer articles than the version that was printed in 1518 and confirmed by the Holy See in 1520 . The later version is more substantial and coherent than its prototype, which is due most likely to the continual changes that were made to the statutes over the course of 70 years. Although the order and sequence (which was based chronologically on when individual privileges were obtained) of the particular entries contained in Bishop Wojciech Radziwiłł's collection were quite random, more recent editions were arranged more methodically. It is likely that the college noticed unavoidable repetitions in chronology over time (e.g., confirmations of certain privileges were noted in the documents that served as records of these privileges). Since there was no reason why this information should be included in the records, it was successively removed. However, editing individual headings and putting them in the correct order proved difficult because a significant number of these entries were applicable to several different areas. Generally, the last version of the statutes contains articles that refer to the same issue. For example, articles 3-7 and 12-18 refer to norms regarding the use of stipends, bona mensae and praestemoniae, especially the distribution of the revenue from bona mensae, the reception of which was dependent on whether the members fulfilled their choir duties. ${ }^{43}$ Articles 23-30 defined the order in which tenement houses and flats should be allocated and normalized the conditions under which they could be taken into possession. ${ }^{44}$ The following five articles, 35-39, pertained to the order of the divine service in the cathedral.$^{45}$ Articles 40-66, defined the Chapter's organization and system as a college, normalized the sequence of the sessions, defined the duties of particular roles and capitular offices, and explained how to appoint and install

\footnotetext{
42 LMAB, f. 43-155, Statuta (...) Ecclesiae Cathedralis Vilnensis, 1584.

$43 \quad$ Ibid., k. 8-10, 12-15.

$44 \quad$ Ibid., k. 16v.-18v.

$45 \quad$ Ibid., k. 20v.-22v.
} 
individual canons and order of precedence. ${ }^{46}$ The way that the articles are formulated is extremely precise, and the writing is distinct. ${ }^{47}$

The documented course of both the general and particular capitular sessions proves that, in matters of dispute that did not explicitly involve sanctions related to the statutes, the Chapter referred to the Cracow Chapter's statutes, to archival files that documented the Chapter's privileges, and to conciliar or synodal resolutions.

The statutes sanctioned the Cathedral Chapter of Vilnius' existence, organization, and functioning as an autonomous college that collaborated with the bishop in governing the Diocese of Vilnius until the end of the $18^{\text {th }}$ century. After the collapse of the Polish-Lithuanian Commonwealth, the Chapter ceased to be relevant in the tsarist's autocracy. The decisions of the governing authorities of the state and the emperor's decrees determined the Chapter's position within the diocese, rather than the norms of the Church, which the occupying forces took into consideration only insofar as these norms promoted the interests of the state.

\section{Bibliography:}

History

\section{Archival Sources}

1. The Lithuanian Academy of the Sciences - Wroblewskis Library - Manuscript Department

2. Fond 43, no. 152, Summa Privilegiorum, Immunitatis, Exemptionum, Libertatum ceterarum eiusmodi Gratiarum in rem ac favorem Status Spiritualis et respective Cathedrae Vilnensis eiusque Illmi Capituli servientium, ex ipsis originalibusad promtiorem notitiam: Confirmatio omnium privilegiorum et Immunitatum exemptionum statutorum venerabile capitulo Vilnensi servientium per Zachariam episcopum Gardiensem ad regnum Poloniae et M. Ducatus Lituniae nuntium apostolicum facta a. 15209 bris $29 \mathrm{~d}$.

3. Fond 43, no. 155, Statuta inclitae Ecclesiae Cathedralis tam a Venerabili Capitulo quam eius Pontificibus edita tum a Sanctissima Sede Apostolica confirmata, [circa 1584].

4. Fond 43, no. 207, Index libri actorum V. Capituli Vilnensi.

$46 \quad$ Ibid., k. 22v.-32.

47 The most current edition and complete version of the Cathedral Chapter of Vilnius' statutes are contained in Wioletta Pawlikowska-Butterwick and Liudasa Jovaišy's work entitled Vilniaus ir žemaičiu katedru kapitulu statutai, which was published in 2015 by Catholic Lithuanian Academy of the Sciences. This work can be found in the Lithuanian Academy of the Sciences' Wroblewskis Library. 
5. Fond 43, no. 210-240, Acta Capituli Vilnensis.

6. University of Vilnius Library - Manuscript Department

7. Fond 1, no. 217, Visitatio generalis Ecclesiae Cathedr. Vilnen. Ab Ill'mo Excell'mo a Rndmo Dn Michaele Ioanne Zienkowicz Episcopo Vilnensi Loc. Or. Anno Dni 1743 Die 13 Maij expedita.

8. Polish Academy of Sciences Library, Cracow

9. Ref. 1963, Statuta inclite Ecclesiae cathedralis Vilnensis ac Sacre divi Stanislai sedis tam a venerabili Capitulo, quamcuius pontificalibus edita et a $\mathrm{S}^{\mathrm{ma}}$ Sede Apostolica confirmata A. 1515.

\section{Printed Sources}

1. Kodeks dyplomatyczny katedry i diecezji wileńskiej. Edited by J. Fijałek, W. Semkowicz. Volume 1, z. 1, Kraków 1948.

2. Kurczewski, J. Kościót zamkowy czyli katedra wileńska w jej dziejowym, liturgicznym, architektonicznym i ekonomicznym rozwoju. Part. 2. Wilno 1910. Part. 3. Wilno 1916.

3. "Summaryjny wypis z protokołów Kapituły Katedralnej Wileńskiej od r. 1501 do r. 1783 Października 22, przez i. w. Xawierego Bohusza, Prałata Kantora Kathedry Wileńskiey uczyniony." In: Opisanie rukopisnago otdielenia Wilenskoj Publicznoj Biblioteki, wypusk 1. Wilna 1895.

4. Kubala, L. Wojna moskiewska, 1654-1655. Warszawa 1910.

5. Kurczewski, J. Biskupstwo wileńskie od jego założenia aż do dni obecnych. Wilno 1912.

6. Morawski, K. Czasy Zygmuntowskie na tle prąów Odrodzenia. Warszawa 1965.

7. Ochmański, J. Powstanie i rozwój latyfundium biskupstwa wileńskiego (1387-1550). Poznań 1963.

8. Pawlikowska-Butterwick, W., Jovaiša, L. Vilniaus ir žemaičiu katedru kapitulu statutai. Vilnius 2015.

9. Plöchl, W. M. Geschichte des Kirchenrechts. Bd 3, Teil 1. Wien 1969.

10. Rachuba, A. "Wilno pod okupacją moskiewską w latach 1655-1661." Lithuania, 1994, nos. 2-3: 63-72.

11. Ulewicz, T. Iter Romano-Italicum-Polonorum, czyli o zwiazkach umystowokulturalnych Polski z Włochami w wiekach średnich i renesansie. Kraków 1999.

12. Zachorowski, S. Rozwój i ustrój kapituł polskich w wiekach średnich. Kraków 1912.

13. Zaleski, W. Święci na każdy dzień. Warszawa 1989. 